\title{
The Analysis of the Use of Technology in Stimulating the Customers' Trust and Loyalty from Marketing Perspectives
}

\author{
Yulia Nurendah \\ \{lia_niceone@yahoo.com\} \\ Institut Bisnis dan Informatika Kesatuan, Jl Rangga Gading no 1 Bogor
}

\begin{abstract}
The SMEs sector contributed 60\% of Rp. 14,000 trillion of Indonesia's GDP in 2018. SME absorbs $96 \%$ of Indonesia's labor absorption of 170 million in 2018. One way to get loyal customers is to satisfy the consumers' needs consistently over time. Based on the results of previous reasearh, it is known that trust have a positive and significant influence on customer loyalty. Various factors affect this, including the certainty that the products have hygienic production processes [4]. This study aims to find out 1) how the production process at RTI 2) how to use production technology at RTI. The analysis used in this study are generally descriptive method analysis, Technology Mapping: Importance Performance Analysis. The results of the analysis are known 1) The technology used in RTI in general has been good based on HACCP 2), The overall analysis of the results shows that the type of technology used is still dominant with semi-mechanical technology.
\end{abstract}

Keywords: Technology Utilization, Customer Trust and Loyalty, SMEs and Cooperatives, Marketing Perspective

\section{$1 \quad$ Introduction}

The SMEs and Cooperative sectors are strategic sectors in Indonesian. The SMEs sector contributed 60\% of Rp. 14,000 trillion of Indonesia's GDP in 2018. SME absorbs $96 \%$ of Indonesia's labor absorption of 170 million in 2018. The contribution of Cooperative members to the national GDP is 30.84 percent of the total national GDP. The contribution of cooperatives to GDP increases to $5.1 \%$ in 2018.

The concept of marketing has now changed to relationship marketing that focuses on maintaining relationships based on values and marketing networks [3]. In relationship marketing, customer loyalty becomes very important. One way to get loyal customers is to satisfy the consumers's needs consistently over time. 
Various factors can affect customer loyalty. Trust have a positive and significant effect on customer loyalty. Various factors effect this, including a hygienic production process [4].

\section{Research Purposes}

a. To find out the production process at Rumah Tempe Indonesia Indonesia

b. To find out the production technology at Rumah Tempe Indonesia Indonesia

\section{$2 \quad$ Literature Review}

\section{Production process}

The production process is defined as an effort in order to create or add a usability of a goods and services by using the source-resources that exist [1].

\section{Technological Approach Approach}

Technology has been defined in many ways, but basically it can be described as the integration of people, knowledge, tools and systems with the aim of improving people's lives [2]. Technically technology is the equipment or devices such as equipment, software, and hardware, which is used to solve operational problems effectively within an organization [2].

\section{$3 \quad$ Research Methodology}

In general the data analysis method used is descriptive analysis method. Data processing and analysis methods that will be used are

a. Technology Assessment.

b. Mapping Technology, Importance Performance Analysis.

c. Benchmarking analysis

\section{$4 \quad$ Results and Discussion}

\section{Preliminary research at Rumah Tempe Indonesia}

Preliminary research [4] took the title "Factors Affecting Customer Loyalty at Rumah Tempe Indonesia". Based on the survey results Relational marketing (X1) has a positive effect on customer loyalty (Y) ; Trust (X2) has a positive effect on customer loyalty (Y) ; Emotional proximity (X3) has a positive effect on customer loyalty (Y).

Various factors affect this, including the certainty that the products have hygienic production processes. One factor that drives consumer loyalty is 
consumer trust that Rumah Tempe Indonesia has a good production process and have a high standard.

\section{Tempe Production Process at Rumah Tempe Indonesia}

Sorting, Washing 1, Immersion 1, Boiling, Immersion 2, Solving soy, Filtering, Washing 2, Draining, Fermentation, Packaging. The entire production process follows a combination of basic prerequisite programs which become the policy of Rumah Tempe Indonesia in carrying out the production process. Rumah Tempe Indonesia has implemented HACCP. The entire tempe production process follows the HACCP guidelines.

\section{Utilization of Technology in Rumah Tempe Indonesia}

Overall analysis shows that the type of technology used is still dominant with 'semi-mechanical technology but has followed applicable standards such as HACCP

Table 1. Application of Technology in Rumah Tempe Indonesia

\begin{tabular}{|c|c|c|}
\hline $\begin{array}{l}\text { Rating } \\
\text { Indicator }\end{array}$ & Ideal Standards & Medium Industry \\
\hline $\begin{array}{l}\text { Soybean harve } \\
\text { sting }\end{array}$ & $\begin{array}{l}\text { 1. harvest age and the right way to harvest } \\
\text { 2. pay attention to the weather at the time of harvest }\end{array}$ & Can be fulfilled \\
\hline $\begin{array}{l}\text { Grading } \\
\text { Production } \\
\text { process }\end{array}$ & $\begin{array}{l}\text { Soybean is free from dirt } \\
\text { 1. The production process follows basic prerequisite } \\
\text { guidelines } \\
\text { 2. The production process follows the HACCP guidelines } \\
\text { 3. The production process follows the SNI guidelines }\end{array}$ & $\begin{array}{l}\text { Can be fulfilled } \\
\text { Meet quality standards }\end{array}$ \\
\hline $\begin{array}{l}\text { Packing } \\
\text { Machines and } \\
\text { Equipment } \\
\text { System } \\
\text { Management }\end{array}$ & $\begin{array}{l}\text { Hieginies packaging and free from contamination } \\
\text { 1. Product contact equipment made of stainless steel } \\
\text { 2. Preventive Maintenance System } \\
\text { Implement a management system (GMP, HACCP, ISO } \\
\text { 9001, Halal) }\end{array}$ & $\begin{array}{l}\text { Fulfilled } \\
\text { 1. Tested } \\
\text { 2. Already applied } \\
\text { Already implementing ISO } \\
\text { 9001, SNI, GMP, Halal }\end{array}$ \\
\hline
\end{tabular}

\section{$5 \quad$ Conclusions}

a. The technology used at Rumah Tempe Indonesia in general has been good because the production process carried out at Rumah Tempe Indonesia has followed a number of standards including basic standards and HACCP prerequisites. 
b. Overall analysis shows that the type of technology used is still dominant with 'semi-mechanical technology but has followed applicable standards such as HACCP 
[1]. Assauri. Sofjan. 2008. Manajemen Produksi dan Operasi. Fakultas Ekonomi Universitas Indonesia. Jakarta

[2]. Hermawan. 2005. Sistem Manajemen HACCP. Edisi Pertama. Bumi Aksara. Jakarta.

[3]. Lupiyoadi, Rambat, 2013, Marketing Services Management, Third Edition, Salemba Empat Publisher, Jakarta.

[4]. Nurendah, Yulia. 2019. Factors Affecting Customer Loyalty at Rumah Tempe Indonesia. Research Paper. 